\title{
Nation-state, Education and the Fabrication of National-Minded Citizens (Introduction)
}

\author{
Daniel Tröhler \\ University of Vienna
}

\section{Abstract}

This Special Issue is dedicated to a social phenomenon that can deliver so much impact precisely because it is largely ignored: Nationalism, and more specifically everyday or banal nationalism and its relationship to education. Concerned people and researchers often discuss globalization or its supposed opposite, aggressive and ostentatious nationalism. They usually do this as moralists, and it is precisely in this role that they always point to others, other perpetrators and other victims, but never actually to themselves. The history of the last 200 years has shown how strongly nationalism creates identities, which, not least - and not coincidentally -, have become extremely visible again just now as mankind has had to fight a global virus, Covid-19. Under the motto, "Looking away is useless," this Special Issue is devoted to the question of the extent to which modern education with its institutions, strategies and practices is related to the discursive reproduction of nationalism as an identity-generating cultural thesis about belonging. While the contributions collected here present individual case studies, the introduction first aims at defining basic concepts such as "nation," "state" and "nation-state." On this basis, approaches to educationally relevant research on nationalism will be discussed, such as the notion of nation as "second nature" of man, the idea of "doing nation" borrowed from gender studies, or, finally - with specific reference to the curricula - the development of "national literacies" as core effects on modern schooling.

Key words: curriculum; doing nation; globalization; national identity; national literacy.

\section{Introduction}

Sometimes single words can work like a magic stick. Once put into action they allow or seduce people into understanding things and contexts that were previously unclear 
or possibly irritating - or even invisible. They are literally key words that magically open closed doors to a new way of understanding the world - and thus create or strengthen identities. In (the history of) education there are many such concepts, for example, in the 18th century, "method"; in the 19th century, "compulsory school"; around 1900, "naturalness"; in the 1960s, "wholeness"; later, "sustainability"; and today, "inclusion" and "educational equality" or "evidence-based." These terms pop up, you don't really know from where, and they immediately find followers, interpreters and also critics. They have the potential to establish a new discourse or to revive an existing one.

One of the terms that shape our perception of the world most is the concept of "globalization," as it came up with the end of the Cold War and seemed capable of making people understand what is happening around them. It was not simply a matter of describing the disintegration of one of the two blocs of this world that had been hostile to each other for almost half a century, but of attributing a world-historical significance to this event. One of the interpreters of this event propagated nothing less than the end of history, because the antagonisms, which in his opinion had been central to the historical development, had finally disappeared (Francis Fukuyama) and another proclaimed the beginning of a world society supported by a shared world culture resulting not least from a harmonized world curriculum (John W. Meyer). Today, both are working at Stanford University, the eminent Cold War university (Lowen, 1997), and we know that the victors write history, not the losers.

But the story of winners and winning is, historically, a fluid thing. First, it is not quite clear whether the "victory" of the West in 1989 was as unambiguously clear as people thought. "The West" has unscrupulously adopted many cultural and political practices that it had previously accused as attributed to the East: cooperative identity, multi-year plans, bench-marks, standardization, surveillance. Second, the global unity that was thought to be discernible was quickly lost, neither Islamist terror nor today's Russia, and certainly not China, fit into the harmonious puzzle of world order dreamed up by the West. And third, we have anything but global harmony, as a global virus has shown. Covid-19 has made visible what the world is made of: nations that want to stand up for themselves first.

May one actually breed animals in northern Germany, cart them on a ghastly 26hour drive through the Alps and then slaughter them in northern Italy with cheap labor from North Africa, take the meat to Spain where it is refined and then flown to England to be sold. If that is globalization, then that is just stupid and it is up to the politicians to make transport costs more expensive and if they don't do that, then they deserve a good kick in the rear end and to be voted out of office: This is not a question of pro or contra globalization, but of common sense, of sensible protection of animals and the environment. Yes, there are the economic-liberal dreams of producing as cheaply as possible and selling as expensively as possible, and there is a policy that tries to realize this. It uses the argument that if you cannot produce extremely cheaply, you would move the business abroad, which would result in the loss of national jobs, 
unemployment and social unrest. Globalization obviously, even in economic terms, is based on national concerns.

\section{The question of the nation}

Above all, however, this obsession with globalization has somehow overlooked the fact that on a real political level the fragmentation of nation-states has been driven forward. At the end of 1992, for example, Czechoslovakia disbanded relatively peacefully into two states, the Czech Republic and Slovakia. Almost at the same time, there followed several years of armed conflict over the future of Yugoslavia with the creation of various nation-states, and from 2003 onwards, the Catalans tried to force their independence from Spain, a process that has not been resolved to this day. At the same time, Scotland wanted to break away from the United Kingdom again and the referendum held in 2014 was rejected mainly because the British Prime Minister, David Cameron, offered Scotland a high degree of independence and financial support if the Scots stayed in the Union; these partly broken promises as well as BREXIT have again strengthened the Scottish independence movement, which has perhaps never been as strong as it is today.

These are the most well-known cases (at least for Europe), but one could also mention the Armenians in Nagorno-Karabakh, the Flemish in Belgium, Greenland in Denmark, the Bretons and Corsicans in France, the Basques in Spain (and France), South Tyrol in Italy or the Hungarians in Romania. Some of these conflicts and movements have been skirmishes to get more subsidies and autonomy from the central government, some have wanted total independence and others have wanted to join another country, like the Romanian Hungarians. But in all of them, even in the case of the strategic activists behind the skirmishes, it has been about the (idea) of the nation, sometimes within a state, sometimes as a separate state, sometimes as an incorporation into another state.

The point is, and this is by no means only the case in Europe, that a surprising number of scholars, under the spell of the magic word globalization have overlooked how the (idea of) nation creates realities that foster a kind of identity of people, so that they are also willing to hurt others, to kill or even to die for this idea of the nation. Unfortunately, this blinder is remarkably true for the scholars in education research. Many researchers in education research mainly do research about their own country, international researchers are not the rule but the exception, and quite a few of the comparative researchers argue that they bring their own country into play as an example of global trends. Now, as Michael Billig aptly remarked, one never sees oneself as nationalistic; "nationalism" is always a phenomenon that affects others (Billig, 1995, pp. 5; 8-9, 15). So when you do research on your own country, you never research "nationalism," because this applies to the others you don't research.

But it is not only because of this that the nation has had a hard time being explored. Another reason is that nationalism is or has become pejorative; and educational science, normally moralized to the bone, is not capable of dealing with such issues; 
or if so, only as the subject of an intervention study on "wrong" behavior, which must be treated educationally. Due to the Great World Wars, the dominant idea around 1900 that earthly salvation can only take place in (one's own!) nation-state has lost much of its rhetorical appeal in the academic context. So you ignore the issue or get involved in the debate on globalization as an activist, critic or analyst. But the facts of the matter, i.e. the questions of nation and national identity, are not solved by this. On the contrary, the field of education is thus left to national(istic) agitators who are bold enough to even use global data for national(ist) purposes (Piattoeva et al., 2019).

Did not Serbia, to take an arbitrary example, in 2001 include religious education in the curriculum in order to connect the nation with (Orthodox) religion in the style of the old Kingdom of Serbia and to confront it with the "Catholic nation" Croatia and the Muslim Bosnians, at the same time it exchanged views with UNESCO, UNICEF, the World Bank and the OECD on internationally assured quality initiatives in the field of education (Bacevic, 2014, pp. 79-124)? And have the Turkish authorities not recently reformed the schools to coincide with an increasingly Islamic state authority, which means, among other things, that certain subjects such as Darwinism are no longer taught and religious schools that train young men to be preachers, the Imam Hatip schools, are becoming increasingly common, ironically or not, in the context of a rhetoric that presumes a globalized agenda (Ayhan Kaya, 2015; Karapehlivan, 2019)? And do not - to go back to a part of former Yugoslavia - the different ethnic groups in Bosnia and Herzegovina create their own textbooks in order to generate ethnic-national minds that weaken the already vulnerable political construction of the state (Peckovic, 2017)?

From a Western European perspective, it is of course tempting to refer to these examples as nationalistic examples elsewhere, which have nothing to do with "us" at all. But that is what we are trying to resist here. This Special Issue is precisely intended to reconstruct one's own national path dependencies, not where nationalism appears as aggression, but where it seems ordinary, where it is "banal," to speak again of Michael Billig (1995); the theme is everyday nationalism and how education is related to its unagitated reproduction. We must therefore begin our case studies in the praxeological field of intersection between nation and state (which are not identical) and in the academic field of intersection between research on nationalism and educational research, or more precisely perhaps of curriculum research, if the latter is understood to mean much more than Lehrplan in the classical German sense (see Horlacher, 2018). This calls for a few conceptual clarifications.

\section{Conceptual Approaches}

The following are attempts to circumscribe central concepts in order to give the individual articles of this special issue a certain conceptual coherence. It is certainly assumed that these terms could also be defined differently, but at least for the connection between nation and education they have proven to be helpful. 


\section{Nation}

To begin with, it should be noted that what is called "nation" in the English language usually does not mean "nation" at all but rather a country, i.e. a (nation-)state. The name of the global organization the United Nations Organization (UN) is a misnomer, because it is not nations that have organized themselves here, but countries or states that see themselves - sometimes rightly, but often not - as nation-states. If the UN were indeed a gathering of nations, the Sami, the Kurds, the Rohingya people, the Tibetans or the Palestinians would also have to be present, but they are not, simply because they do not have their own state. Conversely, Liechtenstein is a member, or Monaco or Andorra, which are certainly states, like Bosnia and Herzegovina too, but perhaps or probably not nation-states.

This raises the question of the concept of the nation, which was for a long time discussed first under the question of the essence of the nation ("What is a Nation?"), and later on also under the question of the historical appearance of nations ("When is a Nation?"). Three key theoretical approaches or theoretical paradigms can be identified that have emerged in the twentieth century to which individual theoretical attempts can be assigned. The first established position is called "primordial" or "perennial," which refers to a specific feature of these theoretical attempts at nationalism that assume that nationality or nationhood is either inherent in human nature or at least goes back very far in the cultural history of mankind (Ichijo \& Uzelac, 2005, pp. 51-55; Özkırıml, 2017, p. 51). In clear demarcation to it, there is the second approach, that of the "modernists," who assume that nationalism is something modern and therefore only arises in connection with the Industrial Revolution and its social and political consequences: Modernity and nation appear as brothers in arms (Ichijo \& Uzelac, 2005, pp. 9-14; Özkırımlı, 2017, p. 81). The third theoretical perspective, "ethnosymbolism," can in a certain sense be seen as a compromise between the first two approaches - a compromise that is not opportunistic but rather well founded: here the thesis of the modernity of national thinking is affirmed, but the possibility of the emergence of this thinking is traced back to pre-modern myths, symbols and practices of loyalty and community that have configured themselves under the conditions of modernity to the idea of nation (Ichijo \& Uzelac, 2005, pp. 89-93; Özkırıml, 2017, p. 154).

The very attempt to assign the existing theories of nationalism to three theoretical approaches that arose in the twentieth century points to a new era, which differs substantially from earlier ones. However, the theoretical attempts, which have become more and more apparent since the mid-1990s, are not themselves yet bundled. In his theoretical overview, Özkırımlı (2017) refers to them as "contemporary approaches to nationalism" (pp. 182-227), among which he identifies a group of theories that propose to understand nationalism as a discourse that can be described as constructivist in the wake of the linguistic turn. The rest of these contemporary approaches follow a more operationalist interest and can therefore be described as functionalist. Therefore, constructivist approaches focus on discourses or "discursive formations" that reproduce 
nationalism on a daily basis (Calhoun, 2007, p. 3 et passim), and functionalist approaches focus on the analysis of political and social processes in given nations, that is nationstates (Wimmer, 2018, p. 21 et passim).

If we assume that the "essentialist" attempts to define the essence of "nation" lead to hardly solvable aporias facing the "cultural turn" in the social sciences (Özkırıml, 2017, p. 182), and if we also assume that the functionalist approaches simply presuppose the idea of "nation" but do not want to clarify it theoretically, then the theoretical approaches that understand the nation as discourse or discursive formation remain. Against this background, "nation" can be understood as a cultural thesis about community and togetherness. This thesis of cultural kinship and identity certainly includes notions of difference as well as conceptions about the "right" ways of dealing with one another. As Ernest Renan already explained in 1882, the reasons for these kinds of cultural commonalities and togetherness can be very diverse: in one case it can be language, in another case religion, then history suffered together, or simply, as Renan attested for Switzerland, the common will to live together in national unity (Renan, 1882). These reasons are quite volatile, as can be seen in the case of Belgium, for example. Belgium's national identity at the time of its separation from the dominant Protestant Netherlands around 1830 was based on the Catholic religion, although it has apparently lost its cultural strength and identity-creating cultural power over the course of time, and Belgium is now characterized by massive ethnic-linguistic contrasts, which are also related to economic inequalities.

This example, however, only shows how strongly "nation" as discourse is dependent on daily reproduction, and that means on institutions that give it duration and stability. The strongest institution is the modern state, which usually also organizes the school in which the future loyal citizens are educated.

\section{State}

There are probably as many attempts to define the state as there are the nation. However, one can expect broad agreement on the minimal definition of "state" proposed over a hundred years ago by the Austrian constitutional law expert, Georg Jellinek. According to him, the state is a social based on at least three constituent characteristics: a territory surrounded by borders (state territory), a group of people living on it as a core population (people of the state) and a state power ruling over this territory (Jellinek, 1900/1905). Later, professional colleagues of Jellinek also pointed out the absolute necessity of a constitution (Maier, 2001, p. 29), and again others pointed to international recognition under international law (Crawford, 2007, p. 422).

Defined territory, an inhabiting people and a political power are thus the three central pillars of a state, to which one today also counts the constitution and international recognition; how important the latter is can be seen, for example, in the case of Taiwan or Kosovo (both are not members of the UN, precisely because they are not states in this legal sense). Of the first three elements, the state power is decisive for our context. It was already understood early on by Jean Bodin as an essential characteristic of a 
state that it can exercise a (sovereign) power (puissance souveraine) independent of both internal and external powers (Bodin, 1576, p. 8). State power is therefore not derived from other instances, but consists of itself. It is only through its existence that it makes a certain territory a state territory and the population living there a state people (Maurer, 2010, \$1).

Power and making, creating or fabricating are thus intimately linked, first, at the level of the state as a whole, with regard to the state people, then, at a lower level, with regard to the individuals as future members of the state people. This is where the school comes in as a state institution that has the power to form these future loyal citizens into becoming members of the state; loyalty - in terms of Bodin, obedience (obeissance) (Bodin, 1576, p. 8) - is essential for a state power to function and to keep the state alive. But, at least in modern ages, power is not unlimited, nor is it evenly distributed in the different states, and that is where the constitution comes into play. The constitutions are, institutionally speaking, the links or pivots between nation and state, the fundament of the respective nation-state.

\section{Nation-state}

Even if researchers disagree as to when one can speak of "nations," there is agreement that the composite nation-state only becomes real from the French Revolution onwards. With its constitutionally legitimized monarchy (1791), which itself legitimized the king as king of the nation (and not of God) who must swear his loyalty to the constitution just like the citizens, citizenship now included all adult men at the nation-state level and was not limited to a few privileged city dwellers. It always implied both a legal category of rights and duties and a moral category of "appropriate" behavior below the legal level (Tröhler, 2020b, pp. 9-10).

Obviously, this combination or amalgam of nation and state presented an overwhelming win-win situation. The "nation" as a cultural thesis about community, difference in belonging together and "right" dealings with each other profits massively from institutions established by state power, which support national rituals (national holidays, national flags, national anthems, national teams in sports, national transport, national currencies, national legislation, national citizenship) and which convey national sentiments, for example on public television or above all in public schools, their structure and curricula. On the other hand, the state or state authority benefits from the fact that people are loyal, i.e. that they adhere to the principles of law and morality that are part of the fundamental principles of the respective states; and, if possible, not only because of the danger of punishment and contempt, but because they want it themselves. This commitment to these principles is what Ernest Renan (1882) meant by the daily plebiscite when he spoke of the nation: it exists only if people accept it as taken for granted and feel identical with it.

The cultural principles of "nation" are linked to the legal system of the state of power over constitutions, which are very different among states. This diversity expresses the 
different ideas about togetherness, difference and dealing with each other. There are constitutions that express very centralistic-hierarchical models of political order, such as France, Belarus or, more recently, Turkey; and there are federal models of order, such as Germany, or federally-based direct democratic models, such as Switzerland. They all represent and create very different cultural, social and political realities into which people must be fitted by learning to identify with this order and being loyal to it. It is no coincidence that once states adopt a new constitution, they usually enact a new school law within a few years, designed to regulate the school system in such a way that it educates future loyal citizens who fit the values that the constitutions express; this is the story of the entire long 19th century in Europe and is still relevant today (Tröhler, 2016). The long and unjustly ignored history of school acts impressively demonstrates this struggle for the right kind of persons/citizens to be educated (Westberg et al., 2019).

Of course, cultural ideas about what one is as a "nation" are divided, and the way in which these values are politically institutionalized in constitutions is sometimes fiercely debated, as we are currently seeing in Poland, Russia, Hungary and Turkey, in particular. It is thus a matter of questions of discursive power struggles, which are decided when the majority of people or people with privileges (wherever they get them from) can agree on an idea and then institutionalize it. Institutionalization gives these dominant ideas power, subsistence and duration, but they only survive if these cultural ideas have also been integrated into the minds of the citizens.

\section{Nation-state and the fabrication of national-minded citizens}

The question of what education in general and school in particular contribute to the shaping of these minds of (future) citizens is the subject of this special issue. For this purpose, it is worth considering the following aspects.

\section{Nation as second nature of mankind}

A well-known term that can be used to express what Renan meant by "daily plebiscite" is that of man's "second nature." What is meant by this is that, in addition to biological nature, man is born into cultural value systems, such as the nation he incorporates, that they become so self-evident and he therefore understands them as a natural part of himself. If culture or cultural imagination is understood as part of nature or as natural, it is outside of negotiation and deliberation, it is part of identity and can even take on religious traits.

The idea of a second nature of man was already popularized in the seventeenth century. One of the first prominent advocates of this idea had been Blaise Pascal in his Thoughts: "Custom is a second nature which destroys the former [nature]" (Pascal, 1670/2007, p. 29). Some thirty years later, Shaftesbury had been describing "second nature" as resulting from processes of enculturation, customization and familiarization, naturalizing cultural categories of merit and virtue: "That which 
is of original and pure Nature, nothing but contrary Habit or Custom (a second Nature) is able to displace" (Shaftesbury, 1699/1711, p. 44). Shaftesbury's text was then translated into French by the Encyclopedist Denis Diderot, who actually translated "second nature" as "other nature" (autre nature) (Diderot/[Shaftesbury], 1745, p. 75). This French translation was then translated into German in 1780, and here the notion is (again) "second nature" (zweyte Natur) (Shaftesbury \& Diderot, 1780, p. 8). So, at that time, people were not yet talking about national patterns of behavior and identity, but about customs. It is exactly this idea that was taken up in the second book of Rousseau's Emile. God, the "author of things," says Rousseau, has not only been taking care of the needs that he has given us, but also for those that we ourselves are giving to ourselves. It is God-given that desires, needs and tastes adapt to the changing conditions of life. Here, customs become a second nature: "The farther we are removed from the state of nature, the more we lose our natural tastes; or rather habit gives us a second nature that we substitute for the first to such an extent that none of us knows this first nature anymore" (Rousseau, 1762/1979, p. 151).

Too little attention was paid to the fact that Rousseau's Emile was a great polemic against the (French) monarchy, which ended in the total failure of the youngster (Tröhler, 2012). Rousseau developed his actual educational vision, for instance, in his Letter to d'Alembert (Rousseau, 1758/1960) and especially in his writing on the reconstruction of Poland, which he interpreted as a republic. The fourth part of these Considerations - titled "education" (Rousseau, 1771-1772/2005, pp. 179-82) is introduced by claiming that this is "the important item," for it is education that "must give the national form [force] to souls" (p. 179). Education is about the soul, and the soul is designed to become nationally framed and formed making up the future citizen, the "true republican," "patriot by inclination, by passion, by necessity" (p. 179). After school education, a twenty-year old Pole has to be nothing else than "a Pole" (p. 180). From today's point of view, this Rousseau is modern, not that of the Emile's, because it conceives of school and curriculum with nation-building in mind.

\section{Doing nation}

The idea that "nation" is understood as natural is omnipresent. We only have to consider that the change from one citizenship to another is called naturalization, an act of state sovereignty that usually presupposes a certain aptitude, which can also be acquired through learning. This refers to procedures, some of which are quite complex, aimed at "fitting" the candidates with the values. There is no broad international comparative study of these educational and socialization processes, but there is an informative study of the various complex processes of naturalization in Switzerland (Helbling, 2008).

Against this background, it is necessary to resort to a pair of concepts that were not developed in the field of research on nationalism, but rather, very fruitfully, in the field of gender studies: Doing Gender. Doing Gender as a pair of terms goes back to the 
concept of Candace West and Don H. Zimmerman in 1987. The authors argued not to understand "gender" as a naturally given personal characteristic that is reflected in the thinking, feeling and acting of a gender-specific identity, but rather emphasize the culturally and socially conditioned active production and representation of gender in everyday life. According to this, gender must not only not be seen as a natural characteristic, nor only understood as generated by the upbringing and socialization of a passive human being, but as always generated in the knowledge of how one should behave as a man or woman, always correspondingly gender-typical behavior (West \& Zimmerman, 1987).

Even if, of course, gender and nation are not the same, they can be understood as similarly constructed, and there are indeed researchers who stress the immanent connection between the two (for instance, Yuval-Davis, 1997). However, the central question of how lived cultural or national values could be implemented in the minds of the next generation has a long history. In the early 18 th century, following the French translation of Theophrastus' character theory by the French moralist, Jean de La Bruyère, and his own continuation, Caractères ou les mours de ce siècle (Bruyère, 1688), a European debate was triggered about the moral function of poets and the way they should deal with moral characters that were seen as "examples." The process of this moral instruction through "examples" was called "emulation," according to which good examples (or those that are considered good by the environment) would encourage imitation in the soul of the readers, while examples of cruel people would arouse feelings of shame (Tröhler, 2006, pp. 53-56).

This idea of imitation, or the hope that good role models would generate imitation and bad ones disgust, persisted throughout the eighteenth century, especially in republican contexts; but it disappeared as the discussion became more individualistic, paradoxically in the age of the long nineteenth century, when the practice of national education had established itself. But the question of how to become moral according to national values and identity is still prevalent today, as a current book, which is dedicated to the question of national identities from the perspective of emotion research, shows: "This volume tackles one of the basic questions in nationalism studies ...: How do people become national?" (Stynen et al., 2020, p. 1). The collected articles of this edited volume are precisely designed to "examine how the nation entered ordinary people's 'insides,"' and for this purpose "this book focuses on their affective lives" (p. 1).

This is certainly a legitimate approach, although identity and emotion are not the same thing (but linked in one way or another), and here educational research has a clear shortcoming that must be regretted: the latest anthology on emotion and education, for instance, which comprises 18 articles in almost 500 pages, does not even mention the word nation or national identity once (Huber \& Krause, 2018). But this topic is dealt with elsewhere, namely in Border(land) Studies, which, on the basis of ego documents (i.e. autobiographies, diaries and personal letters), are dedicated to the question of how children experienced changed citizenship (Venken, 2017). This 
thereby continues a line of research that hit a milestone in Stephen Harp's Learning to be Loyal (1998), in which he studied school governance and instruction in Alsace and Lorraine between 1850 and 1940, in a time when French and German sovereignty alternatively shaped the way children were to be made "natural" Germans (1871-1918; 1940-1944) or "natural” Frenchmen (before 1871, 1918-1940).

\section{National literacies}

One question that the research on nationalism has to clarify again and again is whether it wants to deal with the problem of visible nationalism, with loud, aggressive nationalism or with what Michael Billig (1995) called "banal" nationalism; or as more recent research calls the phenomenon "everyday nationhood" (Fox \& Miller-Idriss, 2008; Skey \& Antonsich, 2017), “everyday nationalism” (Knott, 2015; Goode \& Stroup, 2015), or simply written in this sense as Understanding national identity (McCrone \& Bechhoffer, 2015). And indeed, the aggressive excesses of nationalism are less interesting from an educational point of view and often result in more or less effective activist concepts of tolerance education. Much more interesting seems to be the daily unagitated (re) production of national sentiment, both in everyday life, which is what most authors aim for, and then above all in school, in the curriculum, in learning materials, which most authors ignore, for some reason or other.

If we assume, however, that aggressive nationalism does not arise out of nothing, but rather ignites out of everyday nationalism, especially in times of (subjectively or collectively perceived) need and despair, then there must already be a reservoir of national identity and sentiment that aggressively radicalizes itself in these times. The school plays a specific role here. For a very long time it was thought that school empowers people for life, and this empowerment was often understood as the implementation of important knowledge and central skills. But already the entire development of educational strategies in the Age of Enlightenment placed behind - or in front of - these concerns a completely different one, namely that of moral order, which was Christian and differed according to denomination: progress also had to be tamed in its quite feared consequences (Tröhler, 2020b), and it was just this moral force that made it conceivable in the long nineteenth century to let the masses participate in popular education. Schools did not teach geography, but national geography, not history, but national history, not writing, but national writing (Dahn \& Boser, 2015). It was always about (national) kinds of people that had to be created, not with just any literacies, but with national literacies, which promised meaningful life in the particular national context (Tröhler, 2020a), and even gymnastics lessons served national identification (Tröhler et al., 2017).

Obviously, this is a different term than the literacy term used in the PISA environment, at least at first glance. After all, what is called "literacy" in PISA, like the entire PISA program, does have a national background, namely the United States, which educationalized the Cold War, implemented school reforms and developed a test system 
that was intended to ensure the effects of these reforms. It was this national model that was globally extrapolated via the OECD, and now pretends to be global - instead of imperial (Tröhler, 2013). The national roots are thus just as cleverly concealed as in the fact that the Internet's top-level domain for the United States is the general .com rather than a nation-specific abbreviation (.us) as it is for all other states; that does not make it less national(ist), quite the contrary. Yet these nationally rooted imperial agitations and activities, under the obscuring catchword of "globalization," have found allies all over the world, who discuss, promote, criticize and explain globalization, activists, critics and enlighteners. They all together direct the attention to something that does not exist and prevent the attention from being directed to where reality is made.

\section{Case studies}

It was not the intention of this introduction to create intellectual gags on which the individual essays should work. It was the intention to provide possible clarification on a field of research somewhat buried in education, and the essays are examples of how one can do this kind of research when one is more inspired than enslaved by these ideas.

Here we see cases like Scotland, which was never an independent modern state at all, but perhaps all the more a nation, which after all had the right to design schools for itself, which they did to teach Scottishness, and did so very early on, in the eighteenth and nineteenth centuries (Veronika Maricic). We also realize that supposedly neutral mathematics is not so un-national when it comes to nation and that it serves a national "literacy," as the comparison between France and Switzerland shows (Lukas Boser). And we also see, by the example provided by Rebekka Horlacher, that education of the future citizen is not identical with civic education, but that the latter is a curricular part of the former.

That all these questions are not limited to Europe (but presumably start from here) is shown by Felicitas Acosta's case of Argentina, in which the establishment of secondary schools was linked to the founding of National Institutes that thus wanted to secure education nationally. The extent to which the nation, with its respective cultural concept of identity, was able to "sneak into" the textbooks is shown by a comparative case study, which proves that one and the same event - here the Prussian Wars (1864-1871) was then narrated quite differently in the countries concerned, just as the same thing is never the same (Nicole Gotling). However, the examples do not only bear witness to "normal" school subjects, which we think of when we speak of school, but also to national myths such as about the Alps and cows, which in Switzerland - for example about distributing milk at school - were deliberately used to create national cohesion and identity regardless of social differences (Michèle Hofmann). This already speaks of a religious dimension, which Mette Buchardt reconstructs by proving that institutional secularization simply reappeared in the form of a resacralized nation, based on the case the use of the Holy Bible in schools as a history of a nation during the period of nation state creating in Denmark. 
The intended look beyond the traditional nation-states (France, Germany, United Kingdom, United States) shows how the regulatory idea of the nation-state became so dominant that it reached empires such as the Ottoman Empire and the Habsburg Empire and ultimately led to their dissolution, albeit in very different ways: While the Ottoman Empire was to a certain extent replaced by the Turkish Republic from within by Turkish nationalism (according to the Western model), the foundation of the Austrian Republic was forced from without, it was - conceived as a nation-state by the victorious powers in 1918 - initially a state without a nation, without its own distinct national identity (Kevser Muratovic and Florian Gimpl).

The nation-state was thus an export commodity that dissimilated globally with varying degrees of bliss. A striking example that has remained controversial to this day is the founding of Israel, which followed the logic of the European Zionists and understood Judaism (also) as a nation that has a right to its own territory and sovereignty. How culturally closely related this Jewish nation is to European values is shown by Marva Shalev Marom in the tragic example of Ethiopian Jews who have moved to the Holy Land and been re-educated to find their role, in the end, at the lower end of society. And, last but not least, Stephanie Fox takes up the whole issue and turns it against those who, as a rule, have been firmly convinced of themselves as not being affected by nationalism at all - namely researchers - by demonstrating that the connection between nation and power also has eminent epistemological consequences in science, so that, especially in powerful nation-states, ways of scientific thinking and research have developed that are just as imperial as the idea of the nation-state itself.

\section{Acknowledgement}

A Special Issue is not necessarily the conclusion of a research project, but the beginning. It seems to us that the impact of the nation deserves to be better researched, especially in terms of the role of education in general and school in particular. I would like to thank the editorial team around Tomislav Topolovčan very much for supporting the proposal for this Special Issue in order to further stimulate the international discussion on this issue. The fact that the Croatian Journal of Education bears a national name is a coincidence, and the fact that it bears the name of a nation that only recently, after very painful experiences, was given its own state, may (or may not) have increased sensitivity towards the issue. But we must be careful. Even if the aggressive nationalism in this part of Europe more than twenty years ago has shown itself in such a brutal way: it is not only they who are embedded in national identities, but all of us; some more subtle at certain times, but no less national, but perhaps only less oppressed at the moment. Yes, we tend to impose nationalism on others, but no, that reflex is not appropriate, as these studies show, thus hopefully leading to many others moving towards self-enlightenment. 


\section{References}

Ayhan Kaya, A. (2015) Islamisation of Turkey under the AKP rule: Empowering family, faith and charity. South European Society and Politics, 20(1), 47-69. https://doi.org/10.108 $\underline{0 / 13608746.2014 .979031}$

Bacevic, J. (2014). From class to identity. The politics of education reform in former Yugoslavia. Central European University Press.

Bodin, J. (1576). Les six livres de la république. Livre I. Jaques du Puys.

Billig, M. (1995). Banal nationalism. SAGE.

Bruyère, J. (1688). Caractères ou les mours de ce siècle. Imprimeur du Roy.

Calhoun, C. (2007). Nations matter: Culture, history, and the cosmopolitan dream. Routledge. https://doi.org/10.4324/9780203960899

Crawford, J. R. (2007). The creation of states in international law. Clarendon. https://doi. org/10.1093/law/9780199228423.001.0001

Dahn, N., \& Boser, L. (2015). Learning to See the Nation-State. History, Geography and Public Schooling in Late 19th-Century Switzerland. Bildungsgeschichte. International Journal for the Historiography of Education, 5(1), 41-55.

Diderot, D. [\& Shaftesbury, A.A.C.] (1745). Principes de la philosophie morale; ou essai de M. $S .{ }^{* * *}$ sur le mérit et la vertu. Avec réflexions. Chez Zacharie Chatelain.

Fox, J. E., \& Miller-Idriss, C. (2008). Everyday nationhood. Ethnicities, 8(4), 36-63. https:// doi.org/10.1177/1468796808088925

Goode, J. P., \& Stroup, D. R. (2015). Everyday nationalism: Constructivism for the masses. Social Science Quarterly, 96(3), 17-39. https://doi.org/10.1111/ssqu.12188

Harp, S. L. (1998). Learning to be loyal. Primary schooling as nation building in Alsace and Lorraine, 1850-1940. Northern Illinois University Press.

Helbling, M. (2008). Naturalisations in Swiss municipalities. Amsterdam University Press.

Horlacher, R. (2018). The Same but Different: The German Lehrplan and Curriculum. Journal of Curriculum Studies, 50(1), 1-16. https://doi.org/10.1080/00220272.2017.1307458

Huber, M., \& Krause, S. (Eds.). (2018). Bildung und Emotion. Springer. https://doi.org/10.1007/978$\underline{3-658-18589-3}$

Ichijo, A., \& Uzelac, G. (Ed.). (2005). When is the nation? Towards an understanding of theories of nationalism. Routledge. https://doi.org/10.4324/9780203001509

Jellinek, G. (1905). Allgmeine Staatslehre. Zweite, durchgesehene und vermehrte Auflage. O. Häring. (Original work published 1900)

Karapehlivan, F. (2019). Constructing a "New Turkey" through education. An overview of the education policies in Turkey under the AKP rule. Heinrich Böll Stiftung. https://tr.boell.org/ en/2019/10/01/constructing-new-turkey-through-education

Knott, E. (2015). Everyday nationalism: A review of the literature. Studies on National Movements, 3(1), 1-16.

Lowen, R. S. (1997). Creating the cold war university: The transformation of Stanford. University of California Press.

Maier, W. R. (2001). Staats- und Verfassungsrecht. Fleischer Verlag. 
Maurer, H. (2010). Staatsrecht I. Grundlagen, Verfassungsorgane, Staatsfunktionen. Beck.

McCrone, D., \& Bechhoffer, F. (2015). Understanding national identity. Cambridge University Press. https://doi.org/10.1017/CBO9781316178928

Özkırıml1, U. (2017). Theories of nationalism: A critical introduction (3rd ed.). Palgrave Macmillan. https://doi.org/10.1057/978-1-137-41116-7

Pascal, B. (2007). Pensées. Dover publications. (Original work published in French 1670)

Peckovic, A. (2017). Nation divided: Building identities through Bosnian history. Review of Social Studies, 4(1), 23-40. https://doi.org/10.21586/ross0000044

Piattoeva, N., Tröhler, D., Cowen, R., Acosta, F., Valero, P., Zhao, W., Lingard, B., Grek, S., Silova, I., \& Auld, E. D. (2019). Nations and numbers. The banal nationalism of education performance data. Bildungsgeschichte. International Journal for the Historiography of Education, 9(2), 244-79.

Renan, E. (1882). Qu'est-ce qu'une nation?: Conférence faite à la Sorbonne le 11 mars 1882. Calmann Lévy.

Rousseau, J.-J. (1960). Politics and the Arts: Letter to M. d'Alembert on the theatre (A. Bloom, Trans.). Free Press.

Rousseau, J.-J. (1979). Emile or on education (A. Bloom, Trans., Ed.). Basic Books.

Rousseau, J.-J. (2005). Considerations on the Government of Poland and on its planned reformation. In C. Kelley (Ed.), Jean-Jacques Rousseau, The plan for perpetual peace, on the government of Poland, and other writings on history and politics. The Collected Writings of Jean-Jacques Rousseau (Vol. 11, pp. 167-240). Dartmouth University Press.

Shaftesbury, A. A. C. (1711). An inquiry concerning virtue, or merit. In A. A. C., Third earl of Shaftesbury, Characteristics of Men, Manners, Opinions, Times, Volume II (pp. 3-176). https://doi.org/10.1093/oseo/instance.00040198

Shaftesbury, A. A. C., \& Diderot, D. (1780). Über Verdienst und Tugend, ein Versuch. Neu bearbeitet und erläutert von Herrn Diderot. Aus dem Französischen übersetzt. Dykische Buchhandlung.

Skey, M., \& Antonsich, M. (Eds.). (2017). Everyday nationhood. Theorizing culture, identity and belonging after banal nationalism. Palgrave Macmillan. https://doi.org/10.1057/9781-137-57098-7

Stynen, A., Van Ginderachter, M., \& Núñez Seixas, X. M. (Eds.). (2020). Emotions and everyday nationalism in modern European history. Routledge. https://doi.org/10.4324/9780429424939

Tröhler, D. (2006). Republikanismus und Pädagogik. Pestalozzi im historischen Kontext. Klinkhardt.

Tröhler, D. (2012). Rousseau's Emile, or the fear of passions. Studies in Philosophy and Education, 31(5), 477-489. https://doi.org/10.1007/s11217-012-9314-7

Tröhler, D. (2013). The OECD and Cold War Culture: thinking historically about PISA. In H.D. Meyer \& A. Benavot (Eds.), PISA, Power, and Policy. The emergence of global educational governance (pp. 141-61). Symposium Books.

Tröhler, D. (2016). Curriculum history or the educational construction of Europe in the long nineteenth century. European Educational Research Journal, 15(3), 279-97. https:// doi.org/10.1177/1474904116645111 
Tröhler, D. (2020a). National literacies, or modern education and the art of fabricating national minds. Journal of Curriculum Studies, 1-17. https://doi.org/10.1080/00220272.2020.1786727

Tröhler, D. (2020b). Learning, progress, and the taming of change: The educational aspirations of the age of enlightenment. In D. Tröhler (Ed.), A cultural history in the age of enlightenment (pp. 1-24). Bloomsbury Academic.

Tröhler, D., Westberg, J., \& Berg, A. (Eds.). (2017). Physical Education and the Embodiment of the Nation. Nordic Journal of Educational History, 4(2): Special Issue. https://doi. org/10.36368/njedh.v4i2.92

Venken, M. (Ed.). (2017). Borderland studies meets child studies. A European Encounter. Peter Lang. https://doi.org/10.3726/b11559

West, C., \& Zimmerman, D. H. (1987). Doing Gender. Gender and Society, 1(2), 125-51. https://doi.org/10.1177/0891243287001002002

Westberg, J., Boser, L., \& Brühwiler, I. (Eds.). (2019). School acts and the rise of mass schooling. Education policy in the long nineteenth century. Palgrave Macmillan. https://doi. org/10.1007/978-3-030-13570-6

Wimmer, A. (2018). Nation building: Why some countries come together while others fall apart. Princeton University Press. https://doi.org/10.1515/9781400888894

Yuval-Davis, N. (1997). Gender \& nation. SAGE.

Daniel Tröhler

Department of Education

University of Vienna

Sensengasse 3a, 1090 Vienna, Austria

daniel.troehler@univie.ac.at 


\section{Nacionalna država, obrazovanje i stvaranje nacionalno nastrojenih građana (Uvod)}

\section{Sažetak}

Ovo posebno izdanje posvećeno je društvenom fenomenu koji može imati veliki utjecaj upravo stoga što je većinom zanemaren: nacionalizmu $i$, više specifično, svakodnevnom ili banalnom nacionalizmu i njegovoj vezi s obrazovanjem. Uključeni ljudi $i$ istraživači često raspravljaju o globalizaciji ili njezinoj pretpostavljenoj suprotnosti, agresivnom i razmetljivom nacionalizmu. Oni to obično čine kao moralisti, i upravo u takvoj ulozi uvijek ukazuju na druge, druge počinitelje i druge žrtve, ali, u stvari, nikada na sebe. Povijest je u zadnjih 200 godina pokazala koliko snažno nacionalizam stvara identitete koji su, ne najmanje i ne slučajno, ponovo postali krajnje vidljivi upravo sada kada se ljudska vrsta bori protiv globalnoga virusa, Covida-19. Pod motom „Okrenuti glavu je beskorisno,” ovo posebno izdanje posvećeno je mjeri u kojoj je moderno obrazovanje sa svojim institucijama, strategijama i praksama povezano s diskurzivnom reprodukcijom nacionalizma, kao identetsko-generirajućom kulturološkom tezom o pripadanju. Dok ovdje sakupljeni doprinosi predstavljaju individualne studije slučaja, u uvodu se prvo nastoje definirati osnovni koncepti poput „nacije”, „države” $i$,nacionalne države”. Na toj osnovi raspravljat će se o pristupima obrazovno relevantnim istraživanjima poput zamisli nacije kao „druge prirode” čovjeka, ideje „činjenja nacije" preuzete iz rodnih studija ili, konačno, sa specifičnom referencom na kurikule, razvoja „nacionalnih pismenosti” kao ključnih učinaka na moderno školovanje.

Ključne riječi: činjenje nacije; globalizacija; kurikul; nacionalni identitet; nacionalna pismenost. 